\title{
Rozwój i zmiany klimatu w polityce zewnętrznej UE na przykladzie Afryki
}

Świat stoi przed wyzwaniem polegającym na pogodzeniu rozwoju gospodarczego i poprawy dobrobytu z utrzymaniem równowagi i uszanowaniem potrzeb środowiska naturalnego. $\mathrm{W}$ drugiej połowie $2015 \mathrm{r}$. zostaną podpisane dwa globalne porozumienia, które w istotnym stopniu zdeterminują stosunki międzynarodowe w najbliższej przyszłości. Pierwsze dotyczyć będzie zmian klimatu i zastapi od 2020 r. dotychczasowe porozumienie z Kioto. Drugie ma określać Zrównoważone Cele Rozwoju (Sustainable Development Goals - SDGs) na lata 2015-2030, które z kolei zastąpią realizowane w latach 2000-2015 Milenijne Cele Rozwoju (Millennium Development Goals - MDGs).

Choć negocjacje nad tymi porozumieniami prowadzone są osobno, trzeba dostrzec coraz ściślejsze łączenie polityki rozwojowej z klimatyczną $w$ jednym postulacie wspierania „zrównoważonego i włączającego wzrostu” (Kugiel, 2014). Nowe cele rozwoju będą jak poprzednie, skoncentrowane na eliminacji ubóstwa, ale większy nacisk zostanie położony na ochronę klimatu. Takie stanowisko jest zgodne z priorytetami UE i jej całościową wizją pomocy po 2015 r. Wychodzi także naprzeciw oczekiwaniom pańsw afrykańskich. To one ponosić będą znaczące koszty przystosowania się do skutków zmian klimatu. Bez wsparcia logistycznego, technicznego i finansowego nie zdołają zaadaptować się do nich, co negatywnie wpływać będzie na dalszy rozwój społeczno-gospodarczy kontynentu.

Potrzeba zintegrowanego podejścia do zmian klimatu oraz do rozwoju jest dostrzegana coraz powszechniej. Tylko powiazzanie tych kwestii umożliwia uchwycenie całej złożoności problematyki ubóstwa, która ma charakter wielowymiarowy. Globalny rozwój wymaga uwzględnienia zagadnień związanych z podatnością na zmiany klimatu i przystosowaniem się do nich.

Celem artykułu jest przedstawienie i scharakteryzowanie polityki UE w zakresie przeciwdziałania zmianom klimatu oraz ochrony środowiska na kontynencie afrykańskim w kontekście szerszego celu, jakim jest ograniczenie (eliminacja) ubóstwa. Trzy pierwsze części artykułu mają charakter wprowadzający do problematyki. Na wstępie ukazano w ujęciu teoretycznym istniejące zależności między rozwojem a negatywnymi skutkami zmian klimatu i degradacją środowiska naturalnego. Podjęto próbę odpowiedzi na pytania, w jakim stopniu zmiany klimatu są poważnym zagrożeniem dla rozwoju. Następnie omówiono rolę i znaczenie zmian klimatu i ochrony środowiska w polityce rozwojowej UE oraz sposoby finansowania działań zewnętrznych UE w tym zakresie w latach 2007-2013 oraz 2014-2020. Przedstawiono system instytucjonalny zewnętrznej polityki klimatycznej po traktacie lizbońskim (wskazano jego zalety 
i słabości). Część trzecia artykułu ukazuje negatywne skutki zmian klimatu na kontynencie afrykańskim. Omówiono ekonomiczne, społeczne i polityczne konsekwencje tych zjawisk, które dotykają ten rejon w sposób nieporównywalnie większy niż resztę świata. Część czwarta ma charakter empiryczny. Skoncentrowano się w niej na relacjach UE-Afryka dotyczacych takich kwestii, m.in., jak: negocjacje klimatyczne, zasoby wodne, bioróżnorodność, strefy nadbrzeżne. Omówiono również realizację partnerstwa tematycznego „Zmiany klimatu i ochrona środowiska”, będącego jednym z ośmiu partnerstw Wspólnej Strategii Afryka-UE realizowanych w latach 2007-2013. Przedstawiono także znaczenie tej problematyki w nowym planie działania Wspólnej Strategii Afryka-UE na lata 2014-2017. Ostatnia część artykułu ukazuje najważniejsze wyzwania związane z implementacją polityki rozwojowej i klimatycznej w relacjach UE-Afryka. Choć bowiem istnieje przekonanie o współzależności obu tych polityk, koniecznych działań jest wciąż zbyt mało i często działania rozwojowe i klimatyczne realizowane są osobno.

\section{Rozwój i zmiany klimatu - ujęcie teoretyczne}

Skutki zmian klimatu (powodzie, susze, nieoczekiwane opady i zjawiska ekstremalne) są wyzwaniem szczególnie dla państw rozwijających się, ponieważ w ich gospodarkach dominują sektory wrażliwe na owe zmiany, a możliwości ekonomiczne, technologiczne i ludzkie tych państw są ograniczone. To pogłębia ubóstwo i utrudnia wyjście z biedy, stanowi poważne i stałe zagrożenie dla rozwoju (Yamin, Rahman, Huq, 2011, s. 93; Stern, 2007).

Amartya Sen wskazuje, że jakość życia jest determinowana nie tylko wskaźnikami makroekonomicznymi, ale także jakością środowiska naturalnego. Podkreśla, że: „niepohamowana eksploatacja środowiska przyrodniczego pociaga za sobą istotne pogorszenie standardu życia przez ograniczenie dostępności m.in. czystego powietrza czy wody, a także wzmożone rozprzestrzenianie się chorób" (Fronia, Snarska, Tryjanowski, Szczyciński, 2010, s. 3). Zależność między rozwojem a klimatem potwierdza Międzyrządowy Zespół ds. Zmian Klimatu (Intergovernmental Panel on Climate Change - IPCC) ${ }^{1}$ (IPCC, 2001; IPCC, 2001a), a Priyadarshi R. Shukla zauważa, że problemy rozwoju i klimatu są ,splecione jak węzeł gordyjski”" (Shukla, 2011, s. 116).

Poziom umieralności, napięć społecznych i strat ekonomicznych w krajach rozwijających się jest wysoki. Oddziaływania zmian klimatu zaostrzają te problemy i hamuja realizację celów rozwojowych. Omawiana zależność szczególnie widoczna była podczas realizacji Milenijnych Celów Rozwoju (por.: AfDB, 2012; AMCEN, 2013).

Wspieranie rozwoju i przeciwdziałanie zmianom klimatu to procesy równoległe. Degradacja srodowiska naturalnego przyczynia się do powiększania biedy. Ograniczanie emisji $\mathrm{CO}_{2}$ nie wystarczy. Programy rozwojowe muszą obejmować także zadania związane z przeciwdziałaniem skutkom obecnych i przyszłych zagrożeń klimatycz-

\footnotetext{
1 Organizacja zalożona w 1988 r. przez Światową Organizację Meteorologiczną (WMO) oraz Program Srodowiskowy Organizacji Narodów Zjednoczonych (UNEP) w celu oceny ryzyka związanego z wplywem człowieka na klimat.
} 
nych. Konieczne więc wydaje się uspójnienie polityki klimatycznej i polityki rozwojowej, aby działania jednej nie likwidowały rezultatów drugiej. Ponadto współpraca rozwojowa może skutecznie wspierać synergię między mitygacją, czyli m.in. ograniczeniem emisji gazów cieplarnianych i przestawieniem rozwoju gospodarczego na technologie niskoemisyjne, a adaptacja, czyli przygotowaniem się do obrony przed negatywnymi zjawiskami klimatycznymi i do reagowania na nie (Fronia, Snarska, Tryjanowski, Szczyciński, 2010, s. 4-5; Yamin, Rahman, Huq, 2011, s. 91).

Dominujące na początku XXI w. koncepcje rozwoju pomijały zagadnienie podatności na zmiany klimatu. Skupiały się na czynnikach ekonomicznych - ograniczaniu ubóstwa przez wzrost dochodów. Z tej perspektywy podatność na negatywne zmiany klimatu była postrzegana jako zjawisko przejściowe, które można przezwyciężyć, gwarantując dobre funkcjonowanie rynku i dobre zarządzanie (Yamin, Rahman, Huq, 2011, s. 99; Nyamu-Musembi, Cornwall, 2004).

Podejście oparte na zasadzie zapewnienia trwałych środków utrzymania stanowi najużyteczniejszy punkt wyjścia do pracy analitycznej, związanej z włączeniem kwestii klimatycznych do problematyki rozwoju. W tym podejściu rozwój-skoncentrowany na osobie ludzkiej - rozpatrywany jest w kontekście jej podatności na czynniki zewnętrze: długofalowe tendencje w skali makro (przyrost populacji, przemiany technologiczne), wstrząsy (epidemie, katastrofy naturalne, szoki ekonomiczne), zmiany sezonowe (wahania cen i produkcji, dostępność pożywienia) (Yamin, Rahman, Huq, 2011, s. 106; Carney, 2002).

W badaniach nad klimatem coraz częściej zwraca się uwagę na konieczność integrowania narzędzi prognozowania dostarczanych przez nauki przyrodnicze $\mathrm{z}$ dostarczaną przez nauki humanistyczne wiedzą dotyczącą mechanizmów społecznych, ekonomicznych i politycznych, dzięki którym grupy ludzi przystosowują się do zmian.

Wielkość, skala geograficzna i trwałość zagrożeń klimatycznych wymagają zmierzenia się ze strukturalnymi przyczynami podatności na nie, których nie można traktować cząstkowo, w ramach poszczególnych podejść/teorii/szkół. Zmiany klimatu nie są problemem tylko środowiskowym, tylko ekonomicznym ani tylko przedmiotem Realpolitik lecz mają wszystkie te trzy wymiary. Badania nad polityką środowiskową, globalnymi regulacjami ekonomicznymi i polityką międzynarodową są bowiem potrzebne, by ukazać i analizować aspekty państwowych i międzynarodowych działań odnoszących się do zmian klimatu. Podejście jednostkowe nie wystarcza do zbadania skutków zmian klimatu i ich wpływu na rozwój społeczno-gospodarczy (Yamin, Rahman, Huq, 2011, s. 98-99; Kjellen, 2004).

Tradycyjne ekonomiczne kryteria ubóstwa w znacznym stopniu wyznaczały Milenijne Cele Rozwoju. Opracowując je, nie brano pod uwagę faktu, że bieda przejawia się także w podatności na negatywne zjawiska klimatyczne. Cele wpisywały się w obowiązującą wówczas doktrynę uznającą kwestię zmian klimatu za zjawisko przejściowe. Uważano, że trzeba na nie reagować dopiero wtedy, gdy wywołują katastrofę. Podkreślano jednocześnie przede wszystkim rolę pomocy humanitarnej w ograniczaniu i niwelowaniu strat związanych z katastrofami naturalnymi. Nie uwzględniano natomiast powszechnie znanego faktu, że każdy dolar wydany na przygotowanie się na kataklizmy pozwala zaoszczędzić 4-10 dolarów na kosztach odbudowy (Reid, Alam 2011, s. 125; Yamin, Rahman, Huq, 2011, s. 101). 
Druga połowa pierwszej dekady XXI w. przyniosła ewolucję w zakresie międzynarodowej współpracy na rzecz rozwoju. Dostrzeżono, że ze zmianami klimatu i skrajnymi zjawiskami pogodowymi zmagają się przede wszystkim ludzie biedni, mieszkańcy globalnego Południa, których środki utrzymania zależą od zasobów naturalnych. W szczególności rok 2005 był znaczący dla wyznaczenia ważnych w następnym dziesięcioleciu działań mających na celu zmniejszenie podatności na zmiany klimatu i biedę. To wtedy miały miejsce następujące wydarzenia: Światowa Konferencja Narodów Zjednoczonych na temat Zapobiegania i Ograniczania Skutków Katastrof w Kobe oraz szczyt G-8 w Gleneagles dotyczący zmian klimatu, czystej energii i trwałego rozwoju. Natomiast 16 lutego 2005 r. wszedł w życie Protokół z Kioto. W 2005 r. przyjęto też liczne dokumenty (na forum ONZ i UE) mające na celu usprawnienie działań poszczególnych instytucji dla osiągnięcia MDGs. Wszystko to stało się podstawą debaty nad nowymi celami rozwojowymi i klimatycznymi oraz próbą połączenia obu tych celów w jedną całość. Następowała stopniowa zmiana globalnych uwarunkowań dotyczących międzynarodowej współpracy na rzecz rozwoju.

W dokumencie końcowym konferencji w Rio de Janeiro w 2012 r. (Rio+20) zatytułowanym „Przyszłość, której chcemy” (,, The Future We Want”) strony postanowiły do 2015 r. zdefiniować oraz ogłosić Zrównoważone Cele Rozwoju (UN, 2012) ${ }^{2}$. Ich założeniem jest kontynuowanie walki ze skrajnym ubóstwem, ale także podejmowanie nowych zadań w zakresie sprawiedliwego rozwoju i ochrony środowiska skupiającej się na ograniczeniu zagrożeń zmianami klimatu wynikającymi z działalności człowieka. Tym samym klimat stał się integralną częścią polityki rozwoju.

30 maja 2013 r. Panel Wysokiego Szczebla w sprawie Agendy Rozwoju po Roku 2015 (High Level Panel on the Post-2015 Development Agenda) ${ }^{3}$ opublikowal raport pt. „Nowe Globalne Partnerstwo: Wyeliminowanie ubóstwa i transformacja gospodarek zgodnie ze zrównoważonym rozwojem" (UNIC Warsaw, 2013). W 2014 r. natomiast przedstawiono dwa dokumenty - sprawozdania sekretarza generalnego ONZ na temat ram rozwojowych na okres po 2015 r. oraz wnioski sformułowane przez Otwarta Grupę Roboczą ds. Celów Zrównoważonego Rozwoju. Wszystkie wymienione dokumenty stanowią podstawę negocjacji ostatecznego porozumienia dotyczącego nowych celów rozwojowych, które ma być zawarte jesienią 2015 r.

Równoległe do tych procesów na podstawie Ramowej Konwencji Narodów Zjednoczonych w sprawie Zmian Klimatu (United Nations Framework Convention on Climate Change - UNFCCC) ${ }^{4}$ trwaja wielostronne negocjacje na temat porozumienia,

${ }^{2}$ W 1992 r. odbyła się w Rio de Janeiro pierwsza konferencja ONZ na temat środowiska i rozwoju (tzw. szczyt Ziemi), podczas której przyjęto Deklarację z Rio oraz plan działania na rzecz zrównoważonego rozwoju. Postanowienia tam zawarte stanowily milowy krok w integracji kwestii środowiska i rozwoju.

3 Panel został powolany przez sekretarza generalnego ONZ w lipcu 2012 r. jako jego organ doradczy. Liczyl 27 czlonków. Funkcje wspólprzewodniczących pelnili: premier Wielkiej Brytanii David Cameron, prezydent Liberii Ellen Sirleaf Johnson oraz prezydent Indonezji Susilo Bambang Yudhoyono. W sklad Panelu wszedl komisarz UE ds. współpracy rozwojowej Andris Piebalgs.

4 Ramowa Konwencja została przyjęta podczas szczytu Ziemi w Rio de Janeiro w 1992 r. Wyznaczonym przez nią celem jest stabilizacja ilości gazów cieplarnianych w atmosferze na poziomie, 
które zastąpi Protokół z Kioto (tzw. dialog post-Kioto). Podczas XIII Konferencji Narodów Zjednoczonych w sprawie zmian klimatu (COP 13) w 2007 r., na wyspie Bali, przyjęto tzw. „mapę drogową”, określającą kierunki działań i zakres negocjacji porozumienia ,post-2012",5. Brak zgody co do nowego porozumienia po 2012 r. (wydłużono okres obowiązywania obecnego porozumienia z Kioto) spowodował, że podczas konferencji klimatycznej w Durbanie postanowiono przygotować do 2015 r. nowy, prawnie wiążący dokument, który obejmie wszystkie kraje konwencji klimatycznej i zacznie obowiązywać od $2020 \mathrm{r}$.

Opracowanie nowych międzynarodowych ram prawnych służyć ma zapewnieniu skutecznej realizacji globalnych i zrównoważonych celów rozwoju. Postmilenijny i postkiotowski porządek międzynarodowy w znacznym stopniu wpływa na zmianę koncepcji międzynarodowej współpracy na rzecz rozwoju w kierunku uspójniania polityki rozwojowej i klimatycznej.

\section{Zmiany klimatu i ochrona środowiska w polityce zewnętrznej UE - proces instytucjonalizacji}

Problematyka zmian klimatu i ochrony środowiska staje się coraz ważniejszą dziedziną polityki rozwojowej Unii Europejskiej. Potwierdzają to m.in. Konsensus Europejski w sprawie Rozwoju, Program Tematyczny na rzecz Środowiska i Zrównoważonego Zarządzania Zasobami Naturalnymi, w tym Energią na lata 2007-2013 (The Thematic Programme for Environment and Sustainable Management of Natural Resources including Energy - ENRTP) oraz Strategia Tematyczna i Wieloletni Program Orientacyjny w tym zakresie na lata 2011-2013 (Thematic Strategy Paper and Multi-Annual Indicative Programme 2011-2013). Już w 2003 r. UE przyjęa plan działania (EU Action Plan on Climate Change and Development), w którym postulowała wdrażanie inicjatyw mających na celu ograniczenie skutków zmian klimatu we wszystkich aspektach polityki rozwojowej UE. Dopiero jednak w 2011 r. Rada przyjeła kompleksową strategię UE odnośnie włączenia kwestii środowiskowych do programów pomocy rozwojowej.

Szczególnego znaczenia kwestie te nabrały po 2010 r. Zgodnie z przyjętymi przez UE dokumentami, klimat i ochrona środowiska mają stać się częścią całościowej wizji polityki pomocowej UE po 2015 r. Stanowisko takie przyjęto $\mathrm{m}$.in. w następujących dokumentach: komunikacie Komisji z 5 lutego 2015 r. pt. „Globalne partnerstwo na rzecz eliminacji ubóstwa i zrównoważonego rozwoju po roku 2015"; komunikacie Komisji z 2 czerwca 2014 r. pt. „Godne życie dla wszystkich: od wizji do wspólnego działania”; komunikacie Komisji z 27 lutego 2013 r. pt. „Godne życie dla wszystkich: eliminacja ubóstwa i zapewnienie światu zrównoważonej przy-

który zapobiegłby niebezpiecznym zmianom klimatu spowodowanym dzialalnością czlowieka. UNFCCC weszla w życie w 1994 r.

5 Oficjalna nazwa brzmi: Konferencja Stron Ramowej Konwencji Narodów Zjednoczonych w sprawie Zmian Klimatu (Conference of the Parties to the United Nations Framework Convention on Climate Change-COP). Konferencja stanowi najwyższy organ decyzyjny UNFCCC. 
szłości"; konkluzjach Rady do spraw Ogólnych z 16 grudnia 2014 r. dotyczących programu transformacji na okres po roku 2015; konkluzjach Rady do spraw Ogólnych z 25 czerwca 2013 r. dotyczących nadrzędnego programu działań na okres po roku 2015; rezolucji PE z 25 listopada 2014 r. w sprawie UE (unijnych) i globalnych ram rozwoju po roku 2015.

W komunikacie Komisji pt. „Zwiększanie wpływu unijnej polityki rozwoju. Program działań na rzecz zmian” z października 2011 r. zauważono, że: „Rozwój nie jest zrównoważony, jeżeli szkodzi środowisku naturalnemu, różnorodności biologicznej i zasobom naturalnym oraz zwiększa narażenie/podatność na klęski żywiołowe" (Komisja Europejska, 2011, s. 7). Natomiast w komunikacie z 2 czerwca 2014 r. zaznaczono, że problematyka zmian klimatu jest kwestią o charakterze przekrojowym (Komisja Europejska, 2014, s. 4).

Unia Europejska rozpatruje kwestie zmian klimatu nie tylko w kontekście rozwoju, ale także bezpieczeństwa. Uznaje problem ten za globalne wyzwanie, pogłębiające brak stabilności oraz tworzące zagrożenia dla politycznego ładu (Council of the European Union, 2011). To podejście jest tożsame $\mathrm{z}$ analizą przeprowadzoną przez IPCC, w której przewiduje się, że zmiana klimatu będzie pogłębiać przyczyny brutalnych konfliktów na świecie (IPCCa, 2014).

Wymienione (tylko najważniejsze) dokumenty i stanowiska wskazują, że UE dąży do całościowego i kompleksowego podejścia do zagadnienia rozwoju po $2015 \mathrm{r}$. Jej działania wpisują się w globalne trendy i uwarunkowania. Jednocześnie powiązanie klimatu i rozwoju w polityce zewnętrznej UE należy rozpatrywać w kontekście osiagnięcia przez nią większej spójności i skuteczności na arenie międzynarodowej.

UE odgrywa kluczową rolę w międzynarodowych działaniach na rzecz zrównoważonego rozwoju w skali globalnej i dąży do zachowania tej pozycji. W zmieniającej się rzeczywistości międzynarodowej, gdy pojawiają się nowi donatorzy z rynków wschodzących oraz ustalane są nowe zasady współpracy rozwojowej (m.in. przyjęte podczas konferencji w Pusan w 2011 r.), zadanie to nie będzie łatwe, choć niezwykle istotne dla pozycji UE $\mathrm{w}$ świecie. Należy bowiem rozpatrywać politykę rozwojową i klimatyczną UE jako element unijnego soft power. To przez współpracę rozwojową i klimatyczną UE może oddziaływać na inne podmioty, a także w znaczącym stopniu kształtować rzeczywistość międzynarodową (por.: ETTG, 2014).

W wymiarze instytucjonalnym traktat lizboński wzmocnił zintegrowane podejście do zmian klimatu i rozwoju w działaniach zewnętrznych UE. Przykładem coraz ściślejszego łączenia tych dwóch polityk jest utworzona zgodnie z postanowieniami traktatu struktura instytucjonalna w zakresie zewnętrznej polityki klimatycznej UE. Nowo powstała Dyrekcja Generalna ds. Działań w dziedzinie Klimatu (Directorate-General for Climate Action - DG CLIMA) odpowiada za prowadzenie międzynarodowych negocjacji w sprawie klimatu, zapewnia uwzględnianie polityki w zakresie zmian klimatu we wszystkich politykach unijnych, sprawdza, czy UE osiaga cele dotyczace zmiany klimatu, które mają być osiagnięte do 2020 r., nadzoruje unijny system handlu uprawnieniami do emisji (Climat Action, 2015).

Dyrekcja Generalna ds. Współpracy Międzynarodowej i Rozwoju (Directorate-General for International Cooperation and Development - DG DEVCO) bierze udział w negocjacjach klimatycznych, wspierając DG CLIMA, szczególnie w zakresie wdra- 
żania programu dotyczącego globalnych dóbr publicznych i reagowania na wyzwania o skali światowej (Global Public Goods and Challenges - GPGC), środków dostosowawczych, systemów zapewniania jakości i uwzględniania kwestii klimatu w zewnętrznych instrumentach finansowych UE (Europejskim Funduszu Rozwoju i Instrumencie Współpracy na rzecz Rozwoju - Development Cooperation Instrument, DCI). Ponadto DG DEVCO odpowiada za organizację systemu zbierania danych statystycznych potrzebnych do prowadzenia sprawozdawczości wewnętrznej i międzynarodowej w ramach UNFCCC (Herrero, Knaepen, 2014, s. 4).

Kwestie zmian klimatu znajdują się także w planie prac Europejskiej Służby Działań Zewnętrznych. Odpowiada za nie jeden z jej departamentów tematycznych. Ponadto prowadzona przez ESDZ sieć delegatur Unii bierze udział w programowaniu, zarządzaniu i przeprowadzaniu interwencji klimatycznych w krajach rozwijających się. Obsada delegatur w kluczowych państwach ma w miarę możliwości budżetowych zostać rozszerzona o ekspertów w dziedzinie klimatu. W 2012 r. ESDZ przejęła zwierzchnictwo nad unijną siecią zielonej dyplomacji ( Green Diplomacy Network - GDN), nieformalną grupą utworzoną w 2002 r., której celem jest promocja uwzględniania spraw środowiskowych w stosunkach zewnętrznych. GDN skupia ekspertów w dziedzinie ochrony środowiska z ministerstw państw członkowskich UE w celu dotarcia do większej liczby rządów (Herrero, Knaepen, 2014, s. 5).

Powołanie osobnej Dyrekcji Generalnej ds. Działań w dziedzinie Klimatu, a także włączenie kwestii zmian klimatu do działań ESDZ oraz DG DEVCO miało na celu uwypuklenie tych problemów zarówno w wymiarze politycznym, jak i w polityce zewnętrznej UE.

Wskazuje się jednak na pewne słabości tego systemu. Choć podpisano wstępne porozumienie o współpracy ESDZ i DG CLIMA, mamy do czynienia z dychotomią między ESDZ (która ma charakter polityczny) a DG CLIMA (która jest nastawiona na realizację polityki klimatycznej) (Herrero, Knaepen, s. 2014, s. 4). Niektórzy badacze postrzegają osobną DG CLIMA jako przeszkodę we włączeniu działań w dziedzinie klimatu w szersze ramy stosunków zewnętrznych UE. Zdaniem D. Torneya, ,wzmacnia to tendencję do traktowania zmian klimatu jako odrębnego, technicznego obszaru polityki, leżącego w gestii specjalistów, a nie w szerszym kontekście strategicznym" (Torney, 2012).

Kolejnym wyzwaniem jest zapewnienie uwzględnienia problematyki zmian klimatu w pracach ESDZ. Wystarczy tylko wspomnieć, że w centrali ESDZ pracuje zaledwie jeden pełnoetatowy pracownik zajmujący się tymi zagadnieniami (w Wydziale ds. Problemów Globalnych i Przeciwdziałania Terroryzmowi), (Herrero, Knaepen, s. 2014, s. 8; Torney, 2013).

Jedną z najbardziej krytykowanych zmian w strukturze KE, wprowadzonych przez przewodniczącego KE Jean-Claude'a Junckera, jest połączenie problematyki zmian klimatu z kwestiami energetycznymi w ramach kompetencji jednego komisarza (komisarza do spraw polityki klimatycznej i energetycznej), działającego pod kierownictwem wiceprzewodniczacego do spraw unii energetycznej. Rodzi to pytanie, czy w nadchodzących latach bezpieczeństwo energetyczne będzie miało priorytet nad kwestią zmian klimatu (Herrero, Knaepen, s. 2014, s. 14). 
Komisja Junckera nie połączyła również w stopniu wystarczającym unijnej polityki klimatycznej i zagranicznej. Zakres obowiązków komisarza do spraw polityki klimatycznej i energetycznej nie wspomina jednoznacznie o zrównoważonym rozwoju czy też bezpieczeństwie międzynarodowym. Natomiast w kompetencjach Wysokiego Przedstawiciela Unii do Spraw Zagranicznych i Polityki Bezpieczeństwa brak wzmianki o globalnej walce ze zmianą klimatu. Problematyka klimatu i jego wpływu na rozwój pozostaje jedynie w gestii komisarza do spraw współpracy międzynarodowej i rozwoju. Takie rozwiązanie wskazuje brak politycznego poparcia dla większego zaangażowania w zintegrowanie polityki rozwojowej, klimatycznej i zagranicznej w jedną całość. To sprawi, że trudno będzie zapewnić synergię między programem rozwoju po roku 2015 a Ramową Konwencją NZ w sprawie Zmian Klimatu (UNFCCC) (Herrero, Knaepen, s. 2014, s. 15).

Wzrost znaczenia aspektów środowiskowych i klimatycznych w działaniach zewnętrznych UE, w tym związanych z pomocą rozwojową, ma swoje odzwierciedlenie w skali, zakresie i wielkości wydatków na te działania. W 2003 r. UE przeznaczyła na nie około $100 \mathrm{mln}$ euro w skali roku, w 2012 r. już $800 \mathrm{mln}$ euro. W okresie 2007-2013 KE przekazała krajom rozwijającym się ponad 4,5 mld euro na niwelowanie skutków zmian klimatycznych (Herrero, Knaepen, s. 2014, s. 10).

W nowej perspektywie finansowej na lata 2014-2020 UE zobowiązała się przeznaczyć co najmniej $20 \%$ wydatków z budżetu na przedsięwzięcia związane z ochroną środowiska i zapobieganiem zmianom klimatu. Dotyczy to także działań zewnętrznych UE. Europejski Trybunał Obrachunkowy oszacował, że UE będzie miała do rozdysponowania w ciągu siedmiu lat na te cele $\mathrm{z}$ budżetu (w ramach Instrument Współpracy na rzecz Rozwoju) oraz Europejskiego Funduszu Rozwoju (EFR) około 11,6 mld euro (European Court of Auditors, 2013).

Jednym z trzech programów realizowanych poprzez instrument DCI, w perspektywie finansowej 2014-2020, jest program "Globalne dobra publiczne i wyzwania" o skali światowej (GPGC), który obejmuje takie zagadnienia jak przeciwdziałanie zmianom klimatu i ochrona środowiska naturalnego. Na przedsięwzięcia we wspomnianym zakresie zostanie przeznaczone nie mniej niż $25 \%$ środków z tego programu. Drugi - to program panafrykański (Pan-African programme) mający na celu wsparcie realizacji Wspólnej Strategii Afryka-UE. Z jego funduszy będą finansowanie przede wszystkim przedsięwzięcia o charakterze transregionalnym i kontynentalnym, także z zakresu ochrony środowiska (European Commission, 2013d; European Parliament, 2014).

Pomimo wzrastających nakładów finansowych Europejski Trybunał Obrachunkowy w sprawozdaniu z $2013 \mathrm{r}$. wskazał na pewne przeszkody w realizacji zobowiązań UE w zakresie przeciwdziałania zmianom klimatu. Najbardziej znaczące to brak ogólnie przyjętej definicji „,nowych i dodatkowych" środków finansowych oraz brak wspólnego mechanizmu sprawozdawczości i monitorowania środków finansowych przeznaczonych na likwidację skutków zmian klimatu w UE i jej państwach członkowskich, co doprowadziło do policzenia niektórych kwot podwójnie oraz przekierowania środków $w$ ramach pomocy rozwojowej na projekty w zakresie zapobiegania zmianom klimatu (European Court of Auditors, 2013; Herrero, Knaepen, 2014, s. 10). 


\section{Afryka - podatność na skutki zmian klimatu}

Negatywne skutki zmian klimatu dla zasobów naturalnych i związanych z nimi sektorów gospodarki w największym stopniu dotykają państw Południa, w szczególności Afryki Subsaharyjskiej. W czwartym sprawozdaniu (z 2007 r.) Międzyrządowy Zespół ds. Zmian Klimatu (IPCC) stwierdził w analizie dotyczącej Afryki, że kontynent jest jednym z najbardziej narażonych na skutki zmian klimatu, ze względu na występujące na nim liczne napięcia i jego niewielkie zdolności adaptacyjne. Tezę tę podtrzymano w piątym sprawozdaniu IPCC opublikowanym w 2014 r. (IPCC 2007; IPCC 2014). Odsetek ludzi dotkniętych klęskami humanitarnymi spowodowanymi zmianami klimatu wzrośnie do ponad 50\%, sięgając w roku 2015 poziomu $375 \mathrm{mln}$ osób. W raporcie pt. The Africa Adaptation Gap Report z 2013 r. oszacowano, że adaptacja państw Afryki do skutków zmian klimatu będzie kosztowała od 7 do 15 mld dolarów rocznie do 2020 r. (UNEP, 2013).

Prognozy wskazują jednoznacznie na negatywny wpływ zmian klimatu na ważne na kontynencie afrykańskim sfery: zasoby wodne, rolnictwo, zdrowie, ekosystemy. Wystarczy wziąć pod uwagę tylko kilka danych, by uświadomić sobie skalę problemu. Na przykład na południu Afryki do 2050 r. obszary dotknięte brakiem wody powiększą się o 29\%. Przepływ Nilu obniży się do 2100 r. o $75 \%$. Globalne ocieplenie może ograniczyć opady i skrócić okres wegetacyjny poniżej 120 dni wymaganych przez większość zbóż. Do 2080 r. potencjał produkcyjny zbóż w Afryce Subsaharyjskiej spadnie o około $12 \% \mathrm{w}$ stosunku do notowanego obecnie. Przewiduje się, że w Lagunie Conkouati (w Kongu) na skutek coraz częstszego zalewania jej przez wodę morską może zginąć ponad 50\% ryb. Zmiany klimatu powodować mogą także rozprzestrzenianie się chorób wirusowych (np. malarii, dengi) oraz wzrost podatności na infekcje układu pokarmowego i choroby zakaźne. Główne czynniki klimatyczne, które wpływają na rozwój chorób na kontynencie, to powodzie, susze i ocieplenie. Powyższe przykłady ukazują, iż poprawa zdolności adaptacji państw Afryki do zmian klimatu jest konieczna. Inaczej dalszy rozwój nie będzie możliwy (Nyong, 2011, s. 75-79; Reid, Alam, 2011, s. 123-125).

\section{Współpraca UE-Afryka w zakresie ochrony środowiska i zmian klimatu}

\subsection{Ramy instytucjonalne}

UE wspiera państwa afrykańskie w różnych działaniach dotyczących ochrony środowiska, m.in. w zachowaniu różnorodności biologicznej, ochronie lasów, wód i zasobów morza, w walce z pustynnieniem i degradacją gruntów. UE i Afryka współpracują także w kontekście Ramowej Konwencji Narodów Zjednoczonych w sprawie Zmian Klimatu oraz organizowanych pod egidą ONZ tzw. szczytów Ziemi.

O wadze problematyki ochrony środowiska i zmian klimatu dla relacji UE-Afryka świadczyć mogą przyjmowane przez strony dokumenty i postanowienia, takie jak: umowa z Kotonu (szczególnie art. 32), Wspólna Deklaracja UE-AKP, przyjęta w Port Moresby z czerwca 2006 r., Wspólna Deklaracja UE-Afryka z 21 listopada 2008 r., 
z Addis Abeby (Umowa o partnerstwie, 2000; ACP-EC, 2006; An Africa-EU Declaration, 2008). Tematyka ta jest przedmiotem konsultacji Komisji Europejskiej i Komisji UA, zainicjowanych w czerwcu 2011 r. (Key Deliverables, 2012, s. 25-26).

Jednym z ośmiu partnerstw tematycznych Wspólnej Strategii Afryka-UE (Joint Africa-EU Strategy - JAES) w latach 2007-2013 r. było partnerstwo „Zmiany klimatu i ochrona środowiska" (Africa-EU Climate Change and Environment Partnership). Wśród jego głównych celów należy wyróżnić:

- wzmocnienie dialogu i wypracowanie wspólnego stanowiska, przede wszystkim w kontekście negocjacji dotyczących globalnego i kompleksowego porozumienia w sprawie klimatu;

- wzmocnienie zdolności poszczególnych państw afrykańskich do zapobiegania zmianom klimatu i dostosowania się do nich;

- zwiększenie stopnia przygotowania i świadomości społecznej w zakresie wyzwań, jakie stanowią zmiany klimatu;

- promowanie współpracy państw rozwijających się na globalnym rynku emisji związków węgla (w tym za pomocą mechanizmu czystego rozwoju)

- promowanie i wdrażanie technologii przyjaznych dla środowiska, a także poprawa monitorowania wpływu zmian klimatu na środowisko, m. in. z wykorzystaniem systemów satelitarnych (JAES, 2007; JAES, 2007b; JAES, 2010).

Zmiany klimatu oraz ochrona środowiska i ich wpływ na rozwój kontynentu afrykańskiego były jednym z głównych tematów IV szczytu UE-Afryka w 2014 r. oraz towarzyszących mu wydarzeń (piątego unijno-afrykańskiego forum biznesu oraz unijno-afrykańskiego posiedzenia podmiotów gospodarczych i społecznych). Z okazji szczytu zorganizowano ministerialne seminarium poświęcone klimatowi. Podczas spotkania przyjęto dokument (EU-Africa Ministerial Statement on Climate Change), w którym podkreślono konieczność przeciwdziałania zmianom klimatu, których negatywne skutki nie tylko stanowią zagrożenie dla ekosystemów i środowiska naturalnego, ale szerzej - mają poważne implikacje dla całej gospodarki światowej, rozwoju, bezpieczeństwa i pokoju. W dokumencie potwierdzono współpracę w osiagnięciu nowych celów rozwojowych oraz porozumienia klimatycznego (EU-Africa Ministerial, 2014).

Podczas IV szczytu przyjęto nowy plan działania na lata 2014-2017 regulujący stosunki UE-Afryka w ramach JAES. Obejmuje on pięć obszarów priorytetowych (zastępujących partnerstwo $\mathrm{w}$ ośmiu dziedzinach). Wśród nich wyróżniono zagadnienia globalne i wyłaniające się (global and emerging issues), a jako jedno z kluczowych dziedzin współpracy w tym zakresie wymieniono kwestie ochrony środowiska i przeciwdziałania zmianom klimatu, a także rozwoju po 2015 r. (General Secretariat of the Council, 2014a ib).

Plan działania potwierdził cele i założenie realizowane $\mathrm{w}$ ramach partnerstwa „Zmiany klimatu i ochrona środowiska” w latach 2007-2013. Strony zobowiązały się do współpracy podczas negocjacji nad zrównoważonymi celami rozwoju, a następnie do ich skutecznej implementacji (General Secretariat of the Council, 2014b).

\subsection{Ochrona lasów, różnorodność biologiczna, rybołówstwo, woda}

Afryka została objęta programem FLEGT (Forest Law Enforcement Governance and Trade - Przestrzeganie Prawa, Zarządzanie i Handel w zakresie Leśnictwa) ustano- 
wionym w 2003 r. przez UE. Jest to system zezwoleń i innych metod zapewnienia dostaw do Europy wyłącznie drewna legalnego pochodzenia. W ramach planu działania UE zawiera z państwami rozwijającymi się dobrowolne, ale prawnie wiążące umowy o partnerstwie (Voluntary Partnership Agreements - VPAs) (The European Forest Institute, 2009). Mają one pełnić rolę mechanizmu identyfikacji, wykluczającego z rynku europejskiego drewno pozyskiwane nielegalnie. Ponadto VPAs zawierają obustronne zobowiązania w zakresie przeprowadzenia reform politycznych, zarządzania i uregulowań prawnych odnoszących się do leśnictwa i handlu drewnem. Wśród państw afrykańskich, które zakończyły negocjacje z UE, VPAs podpisały: Ghana (2009 r.), Republika Konga (2010 r.), Kamerun (2010 r.), Republika Środkowoafrykańska (2011 r.) i Liberia (2011 r.). Negocjacje nadal prowadzą: Demokratyczna Republika Konga i Gabon (oba kraje rozpoczełły je w 2010 r.) oraz Wybrzeże Kości Słoniowej (2013 r.) (EU FLEGT, 2015; Hudson, Paul, 2011). VPAs służą UE do ograniczenia niekontrolowanego i nielegalnego wyrębu lasów. Zjawisko to nie tylko negatywnie wpływa na środowisko naturalne, ale także uszczupla dochody państw rozwijających się. Eksploatacja lasów odgrywa bowiem istotną rolę w gospodarce wielu państw, także afrykańskich.

W ramach programu FLEGT 20 października 2010 r. PE i Rada UE przyjęły rozporządzenie ustanawiające obowiązki podmiotów wprowadzających do obrotu drewno i produkty z drewna, tzw. Timber Regulation (nr 995/2010). Zaczęło ono obowiązywać 3 marca 2013 r.

Program FLEGT oraz rozporządzenie PE i Rady należy także rozpatrywać w szerszym kontekście, tj. emisji gazów cieplarnianych. Podczas konferencji klimatycznej na Bali w 2007 r. rozpoczęto rozmowy o programie redukcji emisji dwutlenku wegla z wylesień i degradacji lasów w krajach rozwijających (Reducing Emissions from Deforestation and Forest Degradation - REDD). W Kopenhadze i Cancún, podczas kolejnych konferencji klimatycznych, rozszerzono go o kwestie ochrony i zrównoważonego zarządzania lasami oraz wzmocnienia zasobów wegla w ekosystemach leśnych (conservation and sustainable management of forests and the enhancement of forest carbon stocks), stąd skrót jego nazwy: REDD+ (Drewno, 2010). W perspektywie długofalowej kluczowe będzie podjęcie decyzji o wprowadzeniu REDD + do nowego, prawnie obowiązującego porozumienia klimatycznego po 2020 r. oraz określenie zobowiązań dotyczących finansowania programu. Unia Europejska uznała wsparcie implementacji REDD+ jako jedno z najważniejszych obszarów działań w latach 2014-2017.

Komisja Europejska oraz państwa członkowskie wspierają inicjatywę REDD+ działaniami bilateralnymi, a także współpracując z ONZ (program UN-REDD ${ }^{6}$ ) i z Bankiem Światowym (partnerstwo Banku Światowego na rzecz zmniejszenia emisji gazów spowodowanych wylesianiem - the Forest Carbon Partnership Facility, FCPF). W grudniu 2010 r. Europejski Instytut Leśnictwa ustanowił Instrument EU REDD, finansowany przez KE i część państw członkowskich (Wielką Brytanię, Hiszpanię, Irlandię, Francję). Instrument ma wspierać państwa rozwijające się w przygotowaniu i wdrożeniu REDD + (EU REDD Facility, 2015). Ponadto UE w ramach 7. Programu Ramowego uruchomiła dwa projekty związane $\mathrm{z}$ implementacją REDD+ (Impacts of Re-

6 UN-REDD to program współpracy partnerskiej FAO, UNDP i UNEP. Ma na celu wspieranie krajów rozwijających się w opracowywaniu i wprowadzaniu w życie strategii REDD+. 
ducing Emissions from Deforestation and Forest Degradation and Enhancing Carbon Stocks (I-REDD + ) oraz Reducing Emissions from Deforestation and Forest Degradation through Alternative Land uses in Rainforests of the Tropics (REDD-ALERT)) (Supporting, 2011, s. 29).

W 2007 r. UE przyjęła plan działania w zakresie ochrony różnorodności biologicznej obejmujący zarówno Unię Europejską, jak i państwa rozwijające się (Biodiversity Action Plan to preserve biodiversity both in the EU and in developing countries). Zgodnie z nim UE wspiera w Afryce następujące inicjatywy: Regionalny Program Ochrony i Użytkowania Ekosystemów Afryki Środkowej (Ecosystèmes Forestier de l'Afrique Centrale - ECOFAC), Sieć Obszarów Chronionych w Afryce Środkowej (Réseau des aires protégées d'Afrique Centrale - RAPAC), projekt zapobiegający wyginięciu wybranych gatunków małp, m.in. goryli, szympansów (Great Apes Survival Project - GRASP), projekt monitorujący nielegalne zabijanie słoni (Monitoring the Illegal Killing of Elephants - MIKE). Plan działania JAES 2014-2017 zaleca kontynuację współpracy w tym zakresie (Biodiversity and ecosystem services, 2015).

Rybołówstwo stanowi ważny element gospodarki państw rozwijających się. KE przyjęła w 2000 r. dokument pt. „Rybołówstwo a ograniczenie ubóstwa” (Fisheries and Poverty Reduction), a w 2002 r. zaakceptowano Ramowe Zintegrowane Partnerstwo w zakresie Rybołówstwa (Integrated Framework for Fisheries Partnership Agreements). W dokumentach tych podkreśla się, że jednym z celów polityki rozwojowej UE wobec krajów Afryki jest zrównoważone rybołówstwo, m.in. odbudowa przetrzebionych łowisk, ochrona niektórych gatunków oraz wspieranie przemysłu rybnego.

Pomoc UE w zakresie zarządzania zasobami wodnymi w Afryce Subsaharyjskiej obejmuje takie kwestie jak: nadzorowanie strefy nadbrzeżnej i szczególnie ważnych dla środowiska morskiego terenów przybrzeżnych, a także badania naukowe. W latach 90. XX w. KE zainicjowała przegląd ekologiczny i społeczno-ekonomiczny głównych obszarów namorzynów ${ }^{7}$ w Afryce Zachodniej, Środkowej i Południowej (Łukaszuk, 2007, s. 62-66; Fogler, 2003/2004, s. 65-71).

UE jest największym donatorem pomocy rozwojowej w zakresie zarządzania zasobami wodnymi. Przeznacza rocznie na ten cel średnio około 1,5 mld euro dla państw rozwijających się. To $60 \%$ calej pomocy w tym zakresie dla Afryki. W ramach dialogu politycznego UE w 2002 r. powołała Inicjatywę Wodną (EU Water Initiative - EUWI), która obejmuje: Afrykę, Europę Wschodnia, Kaukaz i Azję Środkowa, kraje śródziemnomorskie i Amerykę Łacińską. Inicjatywa stała się podstawą utworzenia w 2004 r., w ramach 9. EFR Instrumentu Wodnego AKP-UE (ACP-EU Water Facility) z budżetem w wysokości $500 \mathrm{mln}$ euro. Ze środków tych UE współfinansowała m.in. działania podejmowane przez Afrykańską Ministerialną Radę ds. Wody, w ramach programu Afrykański Instrument Wodny (African Water Facility), którego jednym z celów jest poprawa dostępności wody pitnej do $2025 \mathrm{r}$. (Unia przekazała na ten cel $25 \mathrm{mln}$ euro). Współpracowała także z państwami afrykańskimi w zakresie przekazywania im nowoczesnych rozwiązań i know-how dotyczących gospodarki wodnej. Drugi Instrument

${ }^{7}$ Namorzyny to formacja roślinna w regionach tropikalnych przy ujściach rzek i na bagnach powiązanych z morzem. Chronią ląd przed zalaniem, a linię brzegową przed erozją żyje w nich wiele gatunków zwierząt. 
Wodny AKP-UE, z budżetem w wysokości $200 \mathrm{mln}$ euro (powiększonym później o wkład rządu hiszpańskiego w wysokości $12 \mathrm{mln}$ euro), został zrealizowany w ramach 10. EFR na lata 2009-2013. Środki te przeznaczono głównie na zapewnienie wody pitnej i usług sanitarnych, a także na upowszechnienie zasad higieny (ACP - multi-country cooperation - Water, 2015).

We wrześniu 2012 r. Komisja przyjęła komunikat, w którym określano nową strategię współpracy międzynarodowej w zakresie badań naukowych i innowacji w kontekście realizacji programu Horyzont 2020, który zastapił w nowej perspektywie finansowej 7. PR. W komunikacie zaznaczono, że szczególny nacisk położony będzie na współpracę z krajami rozwijającymi się ,w celu przyczyniania się do trwałego rozwoju tych regionów i odpowiedzi na takie wyzwania, jak zielona gospodarka, działania w dziedzinie klimatu, podnoszenie poziomu rolnictwa, bezpieczeństwo żywnościowe i zdrowie" (Komisja Europejska, 2012).

\subsection{Przystosowanie do zmian klimatu}

UE i państwa Afryki podjęły liczne działania w zakresie przystosowania się do zmian klimatu. W 2007 r. Unia Afrykańska zatwierdziła program „,Wielki Zielony Mur dla Sahary i Sahelu" (The Great Green Wall for the Sahara and Sahel Initiative-GGWSSI) ${ }^{8}$. Dotyczy on zjawiska pustynnienia i degradacji gleby oraz konsekwencji tego procesu dla rozwoju społeczeństw i państw regionu. Od 2010 r. realizowany jest przez Organizację Narodów Zjednoczonych do spraw Wyżywienia i Rolnictwa (Food and Agriculture Organization of the United Nations - FAO) program wsparcia dla GGWSSI, obejmujący pięć państw afrykańskich. Natomiast w marcu 2011 r. nastąpiła inauguracja analogicznego programu UE, skierowanego do ośmiu państw afrykańskich (Delegation of the European Union to the African Union, 2011; Delegation of the European Union to the African Union, 2015) ${ }^{9}$. Unia Europejska przeznaczyła na ten cel 1,4 mln euro (całkowity budżet - $1,75 \mathrm{mln}$ euro) w ramach Programu Tematycznego na rzecz Środowiska i Zrównoważonego Zarządzania Zasobami Naturalnymi, w tym Energią na lata 2007-2013 - ENRTP. Pozostałą kwotę przekazały FAO i Globalny Mechanizm Konwencji NZ do Zwalczania Pustynnienia (UN Convention to Combat Desertification Global Mechanism - UNCCD). Program GGWSSI jest powiązany z międzynarodową platformą (partnerstwem) TerrAfrica, mającą na celu zrównoważone zarządzanie gruntami (Sustainable Land Management - SLM). Wkład Unii do TerrAfrica wynosi $10 \mathrm{mln}$ euro (European Commission, 2011, s. 12; TerrAfrica, 2015) ${ }^{10}$. W planie

8 Po zatwierdzeniu programu powołano Panafrykańską Agencję Wielkiego Zielonego Muru (the Pan African Agency of the Great Green Wall - GGWA).

9 Programem UE objęto: Algierię, Burkina Faso, Egipt, Mauretanię, Nigerię, Gambię, Senegal i Sudan. Państwa podlegające programowi FAO to: Czad, Dżibuti, Etiopia, Mali i Niger. W obu przypadkach instytucją odpowiedzialną za implementację programów jest FAO.

${ }^{10}$ W skład Komitetu Wykonawczego TerrAfrica wchodzą: przedstawiciele rządów Ghany, Etiopii, Nigru, Ugandy, Holandii, Norwegii i Francji, NEPAD, UNCCD - Sekretariat, Bank Światowy, Globalny Mechanizm UNCCD, FAO, UNDP, UNEP, IFAD, AfDB, Komisja Europejska oraz organizacje pozarządowe z Afryki - Spong (Burkina Faso) i Suswatch (Kenia). 
działania JAES 2014-2017 podkreślono znaczenie wymienionych programów dla przeciwdziałania degradacji gleby i pustynnieniu.

W 9. EFR przeznaczono $21 \mathrm{mln}$ euro na realizację projektu dotyczącego Afrykańskiego Monitoringu na rzecz Środowiska i Zrównoważonego Rozwoju (African Monitoring of Environment and Sustainable Development - AMESD), obejmującego wszystkie kraje Afryki i trwającego od 2007 do czerwca $2013 \mathrm{r}$. Z kolei $37 \mathrm{mln}$ euro UE przekazała (10. EFR) na program Monitoring na rzecz Środowiska i Bezpieczeństwa w Afryce (Monitoring Environment and Security in Africa-MESA), którego realizację rozpoczęto w 2013 r. Opiera się on na doświadczeniach oraz zasobach uzyskanych dzięki AMESD. Wspomniane programy realizowane są w ramach programów (partnerstwa) dotyczących zmian klimatu i ochrony środowiska. Jednocześnie są powiązane z programami rzecz nauki, społeczeństwa informacyjnego i przestrzeni kosmicznej (obecnie to jeden $z$ obszarów współpracy w ramach priorytetu rozwój społeczny planu działania JAES 2014-2017), gdyż jednym z ich celów jest lepsze wykorzystanie technologii satelitarnych w zarządzaniu zasobami naturalnymi i środowiskowymi. Programy AMESD i MESA stanowią uzupełnienie programu GMES-Africa (Delegation of the European Union to the African Union, 2015b).

Z inicjatywy Komisji Europejskiej w 2007 r. powołano Globalny Sojusz na rzecz Zmian Klimatu (Global Climate Change Alliance - GCCA). Ma służyć pogłębianiu współpracy UE z państwami rozwijającymi się w zakresie walki ze zmianami klimatu. Obejmuje porozumienia o pomocy finansowej i technicznej oraz okresowe spotkania i konsultacje. Wśród beneficjentów znalazły się następujące państwa afrykańskie: Uganda, Benin, Etiopia, Mali, Mauritius, Mozambik, Rwanda, Senegal, Seszele, Malawi, Gambia, Sierra Leone, Tanzania, Demokratyczna Republika Konga (Key Deliverables, s. 26; Global Climate Change Alliance+, 2015).

Z puli 10. EFR, przeznaczonej na GCCA, Unia Europejska wsparła kwotą $8 \mathrm{mln}$ euro inicjatywę pt. Afrykańskie Centrum Informacji Klimatycznej na rzecz Rozwoju w Afryce (The Climate for Development in Africa Programme - ClimDev Africa) ${ }^{11}$. Istotą programu, realizowanego od stycznia 2012 r. do grudnia 2015 r., jest zapewnienie decydentom politycznym, administracji publicznej i społeczności lokalnej kompleksowej wiedzy dotyczącej zjawisk klimatycznych, by minimalizować skutki katastrof naturalnych. ClimDev wspiera także m.in. modernizację sieci obserwacji i rozbudowę infrastruktury komunikacyjnej dotyczących klimatu i systemu wczesnego ostrzegania (Africa-EU Partnership, 2012). Z budżetu GCCA UE współfinansuje również działania subregionalnych organizacji afrykańskich mające na celu włączenie kwestii środowiskowych (dotyczących zmian klimatycznych) do ich strategii rozwoju, m.in. COMESA (4 mln euro) i ECOWAS ( $4 \mathrm{mln}$ euro).

W ramach 7. Programu Ramowego (obszar tematyczny - środowisko i zmiany klimatu), UE wsparła kilka projektów. Przekazała 3,5 mln euro na realizację (trwała od 1 grudnia 2010 r. do 30 listopada 2013 r.) projektu dotyczącego wpływu zmian klimatu

11 Jest to trójstronna inicjatywa Komisji UA, Komisji Ekonomicznej ONZ ds. Afryki (United Nations Economic Commission for Africa - UNECA) i Afrykańskiego Banku Rozwoju. Program koordynuje Afrykańskie Centrum Polityki Klimatycznej (African Climate Policy Centre), dzialajace od 2010 r. pod auspicjami UNECA. 
na rozwój miast w Afryce (The Climate Change and Urban Vulnerability in Africa - Cluva). Głównym jego założeniem było opracowanie metod i strategii adaptacji, które będą stosowane w miastach afrykańskich w celu zarządzania ryzykiem związanym ze zmianami klimatu (Supporting, 2011, s. 17; Cluva, 2015) ${ }^{12}$. Z kolei całkowity koszt projektu pt. Przewidywanie zmian klimatycznych w Afryce Subsaharyjskiej: implikacje i działania adaptacyjne (Climate Change Predictions in Sub-Saharan Africa: Impacts and Adaptations - ClimAfrica) wyniósł 4,6 mln euro, a wkład UE - 3,5 mln euro. Celem projektu, realizowanego w latach 2010-2014, było zwiększenie lokalnych zdolności przewidywania klęsk żywiołowych i ocena wpływu zmian klimatycznych na kluczowe sektory gospodarki i życie mieszkańców, a także przyjęcie lokalnych strategii adaptacyjnych. Obejmował następujące państwa: Burkina Faso, Kongo, Ghana, Kenia, Malawi, Sudan Południowy, Togo (ClimAfrica, 2015). Natomiast celem projektów pt. Zdrowie przyszłości (Healthy Futures) i Kwantyfikacja pogody i wpływ zmian klimatu na poziom zdrowia w krajach rozwijających się (Quantifying Weather and Climate Impacts on Health in Developing Countries - QweCI), realizowanych odpowiednio w latach 2011-2014 i 2010-2013, było zbadanie relacji między zmianami klimatu a liczbą zachorowań i występowaniem różnego rodzaju epidemii w Afryce. Na pierwszy z projektów UE przeznaczyła 3,4 mln euro, na drugi - 3,5 mln euro. Obejmowały następujace państwa: Kenia, Malawi, Rwanda, Senegal, RPA i Uganda (Healthy Futures, 2015; University of Liverpool, 2015).

\subsection{Konferencje klimatyczne - dialog post-Kioto}

Zarówno w dokumentach końcowych szczytów UE-Afryka z 2007, 2010 i 2014 r., jak i w planie działania JAES na lata 2014-2017 (oraz wcześniejszych 2008-2010 i 2011-2013) podkreśla się konieczność wypracowania wspólnego stanowiska podczas negocjacji w ramach UNFCCC, co ma pozwolić na osiągnięcie prawnie wiążącego porozumienia.

Podczas konferencji klimatycznej (COP 15) w Kopenhadze (7-18 grudnia 2009 r.) uzgodniono, a następnie zatwierdzono w Cancún (COP 16; 29 listopada-10 grudnia 2010 r.), ustanowienie specjalnego mechanizmu finansowego tzw. szybkiego startu (fast-start funding). Oznaczało to przyznanie dodatkowych środków, oprócz już wyasygnowanych w wyniku wcześniejszych zobowiązań (w tym w ramach oficjalnej pomocy rozwojowej), w wysokości 30 mld dolarów. W ten sposób finansowano w latach 2010-2012 działania adaptacyjne w państwach rozwijających się związane ze zmianami klimatu. UE przekazała na ten cel 7,2 mld euro. W Cancún przedstawiciele rządów ustanowili Zielony Fundusz Klimatyczny (Green Climate Fund). Docelowo (do 2020 r.) jego budżet ma osiągnąc wartość $100 \mathrm{mld}$ dolarów i służyć ochronie środowiska, adaptacji do zmian klimatu i ograniczeniu emisji $\mathrm{CO}_{2} \mathrm{w}$ państwach rozwijających się (Council of the European Union, 2011a; Council of the European Union, 2011b; Ministerstwo Środowiska RP, 2009; Ministerstwo Środowiska RP, 2010). Przebieg obu kon-

${ }^{12}$ W programie uczestniczy pięć miast: Addis Abeba, Dar es Salaam, Douala, Ouagadougou, St. Louis (Ndar). 
ferencji klimatycznych ukazał ściślejszą niż dotychczas współprace przedstawicieli UE i Afryki. Potwierdziła to kolejna konferencja (COP 17) w Durbanie, w RPA (28 listopada-9 grudnia 2011 r.).

COP 17 szczególnie przyczyniła się do wzmocnienia wielostronnej współpracy UE z Afryką na forum międzynarodowym. Kraje Afryki pragnęły stać się równorzędnym partnerem w dialogu klimatycznym i nie chciały ograniczać się tylko do tematów kontynentalnych. Dowodem takiego podejścia jest zorganizowanie przed konferencja w Durbanie euroafrykańskiego okragłego stołu na temat zmian klimatu z udziałem ponad 200 przedstawicieli polityki, nauki, biznesu, instytucji pozarządowych (14 października 2011 r., w Brukseli) (European Climate Diplomacy, 2011). Wyrazem swoistej solidarności UE z państwami Południa było natomiast zawarcie z nimi, na samej konferencji klimatycznej, tzw. Sojuszu z Durbanu (obejmującego m.in. kraje najsłabiej rozwinięte (LDCs) i małe państwa wyspiarskie (Small Island States).

Unia Europejska i kraje Afryki pozytywnie oceniły przyjęcie tzw. pakietu decyzji z Durbanu (The Durban Package). Składały się na niego trzy podstawowe elementy:

1) platforma działań z Durbanu (Durban Platform for Enhanced Action) - powołana dla zintensyfikowania prac na rzecz ochrony klimatu. Przyjęto plan działania, który ma doprowadzić najpóźniej do 2015 r. do opracowania nowego, prawnie wiążącego porozumienia, które obejmie wszystkie państwa konwencji klimatycznej (UNFCCC) i zacznie obowiązywać od 2020 r.;

2) ustanowienie drugiego okresu obowiązywania Protokołu z Kioto od 1 stycznia 2013 r.;

3) przyjęcie ram instytucjonalnych Zielonego Funduszu ${ }^{13}$ - Niemcy i Dania zgodziły się przekazać ponad $50 \mathrm{mln}$ euro na jego uruchomienie (Ministerstwo Środowiska RP, 2011).

Decyzje podjęte w Durbanie były ważne dla krajów Afryki. Podczas 14. sesji afrykańskich ministrów środowiska (12-14 września 2012 r. w Arushy) podkreślono, że w przyszłości wszelkie decyzje w tym zakresie muszą uwzględniać postanowienia mapy drogowej z Bali, Platformy działań z Durbanu, a także kwestie zapewnienia Afryce zrównoważonego rozwoju. Powinny być także zgodne z zasadą UNFCCC „wspólnej, ale zróżnicowanej odpowiedzialności”, w zależności od możliwości poszczególnych krajów rozwijających się (TWN, 2012). Stanowisko to przedstawiciele Afryki powtórzyli podczas kolejnej konferencji klimatycznej (26 listopada-7 grudnia 2012 r.) w Doha (COP 18). Zaznaczyli jednocześnie, że ,nie oczekują nowych, lecz jedynie implementacji już zatwierdzonych postanowień przez najbogatsze państwa świata" (Africa Demands, 2012; Africa: Finance, 2012). W tym kontekście, w przededniu konferencji w Doha, Unia Europejska potwierdziła zobowiązanie do wniesienia wkładu do Zielonego Funduszu. Także ministrowie ds. finansów UE na spotkaniu 13 listopada 2012 r. zapowiedzieli, że Unia Europejska, mimo trwającego kryzysu gospodarczego, będzie nadal zapewniać krajom rozwijającym się finansowanie przedsięwzięć w zakresie adaptacji do zmian klimatu po 2012 r. (Climate action, 2012; Council of the Europe-

13 Warszawa byla jednym z pięciu miast ubiegających się o przyznanie lokalizacji siedziby Zielonego Funduszu, obok: Bonn (Niemcy), Mexico City, Windhoek (Namibia), New Songdo City (Republika Korei) i Genewy. Ostatecznie wybrano miasto w Republice Korei. 
an Union, 2012). Zgodnie z tym, podczas szczytu w Doha Niemcy, Wielka Brytania, Francja, Dania, Szwecja i KE zobowiązały się przekazać na ten cel łącznie 6 mld euro w latach 2013-2015 (Africa: Cop, 2012). Kolejne konferencje klimatyczne w Warszawie (COP 19) i Limie (COP 20) potwierdziły dążenie zarówno UE, jak i Afryki do wypracowania wspólnego stanowiska na konferencję klimatyczną w Paryżu, w grudniu $2015 \mathrm{r}$.

Należy jednak wskazać pewne problemy w relacjach wzajemnych dotyczące omawianych kwestii. Wciąż brakuje konkretnych ustaleń co do podziału zobowiązań państw finansujących Zielony Fundusz i wskazania metody skutecznego zarządzania jego środkami (tzw. clarity on finance). Nie ustalono np., jaki procent kwoty na przeciwdziałanie zmianom klimatycznym w państwach rozwijających się powinien pochodzić ze źródeł publicznych, a jaki z prywatnych. Państwa uprzemysłowione, takie jak Stany Zjednoczone, Niemcy, Wielka Brytania, Kanada czy Australia, opowiadają się za zwiększeniem inwestycji w sektorze prywatnym. Natomiast kraje grupy G-77, na czele z Chinami, podkreślają, że państwa Północy zobowiązały się zapewnić nowe fundusze z publicznych źródeł. Sektor prywatny i wpływy ze sprzedaży kwot emisji miały stanowić jedynie dodatkowe źródło finansowania. Jeden z negocjatorów południowoafrykańskich tak określił tę sytuację: „mówienie o planach zwiększenia pomocy klimatycznej do 100 mld dolarów rocznie do 2020 r. to zbyt mało" (Africa: Finance, 2012; Pierwszy, 2011).

Istotnym wyzwaniem zarówno dla UE, jak i państw Afryki jest brak jednolitego stanowiska grupy G-77. Wielu badaczy, analityków, a także polityków wskazuje, że podczas negocjacji klimatycznych nie obowiązuje prosty podział na kraje rozwinięte i rozwijające się. Ponadto Chiny często wykorzystują swoją wiodącą pozycję, by forsować korzystne dla siebie rozwiązania.

Kraje Południa, w tym afrykańskie, postulują, by nie dopuścić do wzrostu średniej temperatury na świecie powyżej 1,5 st. C w stosunku do okresu sprzed epoki przemysłowej. Natomiast państwa rozwinięte, m.in. unijne, uważają, że granicą jest wzrost temperatury o 2 st. C. Jednak $z$ inicjatywy UE, wychodzac naprzeciw postulatom krajów Południa, podjęto w Cancún decyzję, by adekwatność celu utrzymania globalnego ocieplenia poniżej 2 st. C została zweryfikowana w latach 2013-2015.

Choć istnieje zgodność między przedstawicielami UE i Afryki co do ogólnych kierunków globalnej polityki klimatycznej, należy się spodziewać różnic zdań podczas omawiania konkretnych propozycji rozwiązań. Ponadto im bliżej końcowych negocjacji, tym większe mogą występować rozbieżności zarówno w łonie UE, jak i wśród państw Afryki. Państwa uczestniczące w drugim okresie z Kioto są odpowiedzialne jedynie za około $14 \%$ światowej emisji gazów cieplarnianych ${ }^{14}$. $Z$ jednej strony uwypukla to potrzebę stworzenia systemu działań w dziedzinie klimatu, w który zaangażowane byłyby wszystkie państwa, z drugiej strony już skala planowanego porozumienia i dążenie, by objęło wszystkich, są wyzwaniem same w sobie. Oczywiście implikuje to wyzwania polityczne, ekonomiczne, a także społeczne.

14 USA odmawiają podpisania Protokohu z Kioto, a Kanada, Rosja, Ukraina i Japonia zrezygnowaly $\mathrm{z}$ jego przestrzegania po $2012 \mathrm{r}$. 


\subsection{Od konferencji Rio+20 do Zrównoważonych Celów Rozwoju}

Kwestie klimatu, ochrony środowiska oraz rozwoju w relacjach UE-Afryka należy rozpatrywać także w kontekście organizowanych pod egidą ONZ tzw. szczytów Ziemi. Podczas przygotowań do konferencji Rio +20 Unia Europejska przyjęła 11 października 2011 r. oraz 9 marca 2012 r. konkluzje w tej sprawie. Zdaniem UE głównym efektem Rio +20 powinna być mapa drogowa zielonej gospodarki, określająca konkretne cele i działania na poziomie międzynarodowym, razem z pakietem reform, dotyczących m.in. podniesienia rangi instytucjonalnej UNEP (Council of the European Union, 2012; Council of the European Union, 2011a; W kierunku, 2011).

Państwa Afryki określiły swoje stanowisko na konferencję w deklaracji pt. Afrykański Konsensus na Rio +20 (Africa Consensus Statement to Rio +20 ). Dokument, charakteryzujący się kompleksowym podejściem państw Afryki do problemu zrównoważonego rozwoju, został zaakceptowany przez Unię Afrykańską w styczniu 2012 r. Wezwano w nim przedstawicieli zebranych na konferencji w Rio „do wznowienia wysiłków w zakresie ODA, redukcji zadłużenia, transferu zielonej technologii czy sprawiedliwego handlu, by pomóc Afryce osiągnąć rzeczywisty zrównoważony rozwój" (African Union, 2012; Africa Consensus, 2012). Warto zaznaczyć, że państwom azjatyckim i latynoamerykańskim, w odróżnieniu od afrykańskich, nie udało się wypracować wspólnego stanowiska na konferencję w Rio.

UE i państwa afrykańskie dążyły do zbliżenia swoich stanowisk na konferencję Rio+20. Taką sytuację należy uznać za ważny element implementacji postanowień Wspólnej Strategii Afryka - UE, która m.in. wskazuje potrzebę rozwiązywania problemów globalnych. Ponadto istniało przekonanie, że współpraca afrykańsko-europejska przed i w czasie konferencji klimatycznej w Durbanie (vide: okrągły stół) zostanie podtrzymana także w trakcie spotkania w Rio. Pod auspicjami Unii Afrykańskiej, 27 marca 2012 r., ambasadorowie państw afrykańskich akredytowani w Brukseli spotkali się z przedstawicielami UE, by przedstawić swoje stanowisko na szczyt w Rio (Africa-EU Partnership, 2012). Natomiast 15 czerwca 2012 r., na spotkaniu Rady Ministrów AKP-UE w Port Vila, ogłoszono wspólną deklaracje. Strony wezwały w niej do przyjęcia podczas konferencji Rio +20 ambitnych i zorientowanych na rezultaty działań w zakresie zielonej gospodarki i zrównoważonego rozwoju. Jednocześnie zaznaczyły, że owe działania muszą uwzględniać zasadę poszanowania wyboru przez dany kraj własnej ścieżki rozwoju (free to determine its own path to development). Zauważono bowiem, że nie jest możliwe stworzenie uniwersalnego modelu rozwoju dla wszystkich państw. Podkreślono także znaczenie tzw. niebieskiej gospodarki (blue economy), tj. zasobów morskich i oceanów, dla przetrwania oraz rozwoju krajów AKP, zwłaszcza małych państw wyspiarskich (ACP-EU Council, 2012; ACP, EU take, 2012; Europe and Former, 2012).

Wynik konferencji spotkał się z umiarkowanym entuzjazmem przedstawicieli UE i Afryki. Niektórzy ocenili go nawet dość chłodno. Z jednej strony, uznano za istotny fakt potwierdzenia przez uczestników znaczenia zrównoważonego rozwoju dla przyszłości ludzkości (Ighobor, 2012) ${ }^{15}$. Z drugiej, obie strony podkreślały, że w deklaracji

15 Janez Potočnik, komisarz UE ds. środowiska, uznał dokument za istotny krok naprzód, w realizację którego Unia Europejska powinna się zaangażować. Z kolei Jo Leinen, członek PE, zauważył. 
końcowej zabrakło jasnych definicji, ram czasowych i konkretnych rozwiązań dotyczących finansowania zrównoważonego rozwoju (Rio+20, 2012).

Minister środowiska Danii, państwa sprawującego w okresie konferencji prezydencję w UE, stwierdziła, że „UE dążyła do bardziej konkretnego i ambitnego wyniku konferencji, więc w tym względzie postanowienia z Rio nie są satysfakcjonujące" (Rio+20: Agreement). Dość jednoznaczną negatywną ocenę szczytu zaprezentował Zespół ds. Postępu Afryki (Africa Progress Panel), na którego czele stoi byly sekretarz ONZ Kofi Annan. W wydanym oświadczeniu członkowie zespołu stwierdzili, że wyniki konferencji są „zbyt ogólnikowe” (too vague), „brak zdefiniowanych i mierzalnych celów zrównoważonego rozwoju [...]" (Ighobor, 2012). A należący do niego M. Yunus i M. Camdessus zauważyli w jednym z artykułów prasowych, że „Rio nie dostarczyło tego, czego oczekiwano w Afryce" (Yunus, Camdessus, 2012).

Wbrew stanowisku UE i państw Afryki (zwłaszcza Francji i Kenii) nie przekształcono Programu Środowiskowego Organizacji Narodów Zjednoczonych (UNEP) w wyspecjalizowaną Agencji ds. Środowiska. Nie zgodzono się na utworzenie funduszu w wysokości 30 mld dolarów, którego celem byłoby finansowanie projektów zrównoważonego rozwoju (m.in. wspierających przejście do modelu ,zielonej gospodarki”).

Dokumenty, przyjęte w następstwie decyzji Rio +20 m.in. przez ONZ, spotkały się już z uznaniem zarówno UE, jak i państw Afryki. Precyzowały bowiem przyszłe cele rozwojowe i były zgodne z postulatami obu stron. W dokumencie końcowym IV szczytu UE-A fryka (plan działania), przywołującym deklarację z Port Vila, podkreślano, że ostateczny kształt, a następnie implementacja SDGs są kluczowe nie tylko dla dalszego rozwoju kontynentu afrykańskiego, ale także dla relacji UE - Afryka (General Secretariat of the Council, 2014a).

\section{Zakończenie}

Unia Europejska i państwa Afryki podkreślają konieczność zintegrowanego podejścia do rozwoju i klimatu. Podejmowane przez obie strony działania służą uspójnieniu polityki rozwojowej i klimatycznej. Są też zgodne z głównymi założeniami globalnej polityki po 2015 i $2020 \mathrm{r}$.

1. Stworzony model współpracy UE-Afryka w zakresie przeciwdziałania zmianom klimatu i ochrony środowiska oparto na wymiarze formalnym i instytucjonalnym (Układ z Kotonu, partnerstwo tematyczne JAES 2007-2013, plan działania JAES na lata 2014-2017), politycznym (postanowienia szczytów UE-Afryka oraz deklaracje współpracy UE-AKP oraz UE-Afryka) i finansowym (EFR oraz Instrument na rzecz Współpracy Rozwojowej).

2. Realizowane przez UE na kontynencie afrykańskim projekty i programy mają na celu wzmocnienie zdolności adaptacyjnych i mitygacyjnych państw regionu, a tym samym ograniczenie negatywnych skutków zmian klimatu. Obejmują szeroki wachlarz

że UE powinna traktować dokument końcowy jak motywację do realizacji wlasnych, często bardziej ambitnych celów. Prezydent RPA J. Zuma podkreślił, że szczyt przyczynil się do przypomnienia liderom światowym o problemach globalnych. 
działań: ochronę lasów, zapewnienie różnorodności biologicznej, zarządzanie strefą nadbrzeżną i szczególnie wrażliwymi dla środowiska morskiego terenami przybrzeżnymi, rozwój rybołówstwa, przeciwdziałanie degradacji gleby i pustynnieniu.

3. Równocześnie z pogłębianiem współpracy euroafrykańskiej podjęto się reformy polityki rozwojowej i klimatycznej w UE i w krajach Afryki (na szczeblu regionalnym, subregionalnym i państwowym). Traktat lizboński wzmocnił powiązania między tymi politykami w aspekcie działań zewnętrznych UE przez stworzenie nowych mechanizmów decyzyjnych i finansowych. Dowodzi tego nowa perspektywa finansowa i architektura instytucjonalna. Państwa afrykańskie natomiast formalnie włączyły aspekty środowiskowe do swoich strategii rozwoju społeczno-ekonomicznego. Potwierdzeniem jest przyjęta przez UA deklaracja z Addis Abeby ze stycznia 2007 r. Ponadto podczas szczytu UA 24 sierpnia 2009 r. przyjęto pierwsze wspólne stanowisko na konferencję klimatyczną. Wzmacniało to pozycję państw afrykańskich w negocjacjach i miało na celu podkreślenie roli zmian klimatu jako problemu całego kontynentu na drodze do trwałego rozwoju. Znaczącą rolę w tym zakresie zaczął odgrywać Afrykański Bank Rozwoju.

4. Współpraca UE z Afryką dotycząca zmian klimatu i ochrony środowiska została przeniesiona na szerszy, multilateralny szczebel. Przyczyniła się do wypracowania wspólnych stanowisk w procesie post-Kioto i post-MDGs, czego dowodem są np. deklaracja z Port Vila i deklaracja ministerialna UE-Afryka.

5. Współpraca unijno-afrykańska stała się impulsem dla dialogu post-MDGs oraz post-Kioto. Realizowane w ramach JAES działania są swego rodzaju modelem dla przyszłych relacji Północ-Południe w tym zakresie.

Jednocześnie należy wskazać problemy we współpracy klimatycznej i rozwojowej UE z krajami Afryki. Mają one charakter zarówno wewnątrzunijny, afrykański, międzyregionalny (unijno-afrykański), jak i globalny.

1. Zdolność UE do prowadzenia efektywnej i zintegrowanej dyplomacji w zakresie problematyki klimatycznej i rozwojowej pozostaje ograniczona. Przyczyny takiego stanu rzeczy to: nieuwzględnianie polityki klimatycznej w szerszych ramach stosunków zewnętrznych UE; ograniczone fundusze na zewnętrzne działania klimatyczne (w obrębie DG CLIMA i ESDZ); ograniczone zaangażowanie w rozwiązywanie kwestii klimatycznych na poziomie politycznym i na wyższym szczeblu kierownictwa w ESDZ oraz w delegaturach UE; rozdźwięk między celami dyplomacji klimatycznej a dostępnymi zasobami i możliwościami; powszechnie występujące różnice między celami wewnętrznymi i zewnętrznymi Europy w dziedzinie klimatu i energii (stawianie kwestii energetycznych nad klimatycznymi) oraz rozbieżne interesy państw członkowskich UE.

2. Niewystarczające uwzględnienie aspektów środowiskowych w politykach i strategiach poszczególnych krajów Afryki. Choć istnieje świadomość zagrożeń związanych z negatywnymi skutkami zmian klimatu, kwestie rozwoju gospodarczego pozostaja priorytetowe (poteguje to trwajaca obecnie w Afryce koniunktura). Słabe zdolności przystosowawcze Afryki mają też inne przyczyny, takie jak: wojny i konflikty, słaby potencjał naukowy, korupcja.

3. Pojawienie się nowych dawców pomocy (Chin, Indii, krajów arabskich), także niepaństwowych (np. fundacji prywatnych), komplikuje system współpracy rozwojowej. Kraje zachodnie, zamiast kształtować go same, będą musiały w większym stopniu 
uwzględnić postulaty innych państw. Im więcej asertywnych partnerów, tym trudniej będzie wypracować uniwersalne standardy udzielania pomocy oraz utworzyć globalne partnerstwo na rzecz rozwoju (Kugiel, 2014). To samo dotyczy kwestii klimatycznych. Rosnąca rola państw zaliczanych do tzw. rynków wschodzących przekłada się na ich coraz silniejszą pozycję podczas negocjacji klimatycznych, czego najlepszym dowodem była konferencja klimatyczna w Kopenhadze.

4. Wskutek światowego kryzysu gospodarczego kraje Zachodu są mniej chętne do finansowania pomocy najbiedniejszym. Tym samym dążą do ściślejszej współpracy z sektorem prywatnym. Brak tutaj jednak zgodności między UE a Afryką co do roli tego sektora w finansowaniu działań klimatycznych i rozwojowych oraz zasad ksiegowania tego typu wydatków.

5. Słabość mechanizmów partnerstwa klimatycznego JAES jest wypadkową słabości instytucjonalnej i politycznej zarówno UE, jak i krajów Afryki (Unii Afrykańskiej). Wspólną Strategię krytykuje się za zbyt mało przejrzystą strukturę instytucjonalną. Odbywające się dwa razy do roku posiedzenia wspólnej grupy zadaniowej UE i Unii Afrykańskiej, także dotyczące klimatu i rozwoju, są zbyt biurokratyczne i nie przynoszą oczekiwanych postępów.

6. Istotny dla funkcjonowania Wspólnej Strategii, m.in. w zakresie klimatu i ochrony środowiska, jest problem historycznej odpowiedzialności państw rozwiniętych i rozwijających się za wywołanie efektu cieplarnianego i zmian klimatu. Determinuje on postawę obu stron. Dostrzec można nieufność i podejrzliwość we wzajemnych relacjach.

7. Angażowanie się w rozwiązywanie globalnego problemu zmian klimatu jest wyzwaniem dla kryteriów racjonalności politycznej, gdyż beneficjentami tych działań będą nie współczesne, lecz przyszłe pokolenia. Ta racjonalność przyczynia się do zbyt biernej postawy przedstawicieli UE i Afryki w chwili podejmowania decyzji w kwestiach zapobiegania zmianom klimatu i rozwoju.

UE i kraje Afryki dążą do podpisania kompleksowych umów w sprawie klimatu oraz programu rozwojowego na okres po 2015 i po 2020 r. Obie strony zdają sobie sprawe, że brak synergii między tymi dwiema politykami będzie miał konsekwencje w postaci zagrożeń politycznych, ekonomicznych i bezpieczeństwa, które mogą poważnie przeszkodzić w realizacji interesów zarówno UE, jak i krajów afrykańskich.

\section{Bibliografia}

ACP - multi-country cooperation - Water (2015), http://ec.europa.eu/europeaid/regions/african-caribbean-and-pacific-acp-region/acp-multi-country-cooperation/acp-eu-water-facility en, 10.09.2015.

$A C P, E U$ take joint stand on sustainable development at Rio +20, ,ACP Press Release” z 21 czerwca $2012 \mathrm{r}$.

ACP-EC (2006), African, Caribbean and Pacific Group of States and Council of the European Union, ACPEC Cotonou Agreement: Joint ACP-EU Declaration on Climate Change and Development (ACP-CE 2108/1/06 REV 1), Brussels, 30.06.2006.

ACP-EU Council of Ministers 37th meeting, Port Vila, 14-15 June 2012, Joint Declaration on Rio+20, Brussels, 15.06.2012 r., 11459/12, PRESSE 271. 
AfDB (2012), Solutions for a Changing Climate: the African Development Bank's Response to Impacts in Africa, Tunis: African Development Bank.

Africa Consensus Statement to Rio +20 , The Africa Regional Preparatory Conference for the United Nations Conference on Sustainable Development (Rio+20), Addis Ababa, Ethiopia, 25.10.2011, E/ECA/CFSSD/7/Min./3, http://www.uncsd2012.org/content/documents/325Final\%20Africa\%20Consensus\%20Statement\%20to\%20Rio20.pdf, 11.09.2015.

Africa Demands Implementation of Climate Change Pledges At Doha, „AllAfrica” z 5 grudnia 2012 r.

Africa: Cop18 Ends in New Commitment Period Under Kyoto Protocol, „SAnews.gov.za” z 10 grudnia $2012 \mathrm{r}$.

Africa: Finance Key in COP18 Talks, „SAnews.gov.za” z 6 grudnia 2012 r.

Africa-EU Partnership (2011), Engaging with Africa on Climate Change, http://ec.europa.eu/cli$\mathrm{ma} /$ events/articles/0043_en.htm, 10.09.2015.

Africa-EU Partnership (2012), EU 8 Million Euro grant to strengthen Africa's response to climate change, 1.05.2012, http://www.africa-eu-partnership.org/newsroom/all-news/eu-8-million-euro-grant-strengthen-africas-response-climate-change, 10.09.2015.

Africa-EU Partnership (2012a), The road to Rio $+20:$ AU-conference on common African position and cooperation with the EU, 3.04.2012, http://www.africa-eu-partnership.org/newsroom/all-news/road-rio20-au-conference-common-african-position-and-cooperation-eu, 12.09.2015.

African Union (2012), Decisions, Resolution and Declarations, Assembly of the African Union, Eighteenth Ordinary Session, Addis Ababa, Ethiopia, 29-30 stycznia 2012 r., Assembly/AU/Dec.391-415(XVIII), Assembly/AU/Res.1(XVIII), Assembly/AU/Decl.1-3(XVIII).

AMCEN (2013), Gaborone Declaration on Climate Change and Africa's Development, Gaborone. An Africa EU Declaration on Climate Change, 2008.

AU/AMCEN (2009), Africa's Common Position: Key Political Messages Agreed by African Negotiators, http://www.africaclimatesolution.org/news.php?id=5703, 12.09.2015.

Biodiversity and ecosystem services (2015) https://ec.europa.eu/europeaid/sectors/environment/biodiversity-and-ecosystem-services_en, 10.09.2015.

Carney D. (2002), Sustainable Livelihoods: Approaches, Progress and Possibilities for Change. Londyn, DFID (Department for International Development).

ClimAfrica (2015), http://www.climafrica.net/index_en.jsp, 11.09.2015.

Climate Action, http://ec.europa.eu/clima/about-us/mission/index_en.htm, 10.09.2015.

Climate action: Doha conference must lay the foundations for the 2015 global climate deal, Brussels, „Press Release” z 23 listopada 2012 r.

CLUVA (2015), http://www.cluva.eu/, 11.09.2015.

Council of the European Union (2011), Council conclusions on EU climate diplomacy, 3106th Foreign Affairs Council Meeting, Brussels, 18.07.2011.

Council of the European Union (2011a), Rio+20: towards achieving sustainable development by greening the economy and improving governance. Council conclusions, Brussels, 11.10.2011.

Council of the European Union (2011b), Council Conclusions Follow-up to the Cancin Conference. 3075th Environment Council meeting, Brussels, 14.03.2011.

Council of the European Union (2011c), Council Conclusions on climate finance, 3115th Economic and Financial Affairs Council meeting, Luxembourg, 4.10.2011.

Council of the European Union (2012), Conclusions on the Preparations for the 18th session of COP 18 to the UNFCCC and the 8th session of the Meeting of the Parties to the Kyoto Protocol (CMP 8), (Doha, Qatar, 26 November-7 December 2012), 3194th Environment Council meeting, Luxembourg, 25.10.2012. 
Council of the European Union (2012a), Rio+20: Pathways to a Sustainable Future. Council conclusions, 3152th Environment Council meeting, Brussels, 9.03.2012.

Delegation of the European Union to the African Union (2011), Great Green Wall for Sahara and Sahel - Combat desertification, improving food security and climate change adaptation, Addis Abeba, 29.09.2011, http://eeas.europa.eu/delegations/african_union/press_corner/ all_news/news/2011/20110929_01_en.htm, 12.09.2015.

Delegation of the European Union to the African Union (2015), http://eeas.europa.eu/delegations/african_union/eu_african_union/development_cooperation/index_en.htm, 12.09.2015.

Delegation of the European Union to the African Union (2015b), http://eeas.europa.eu/delegations/african_union/eu_african_union/development_cooperation/index_en.htm, 12.09.2015.

Drewno i gospodarka drzewna (2010), „Dokument tematyczny”, czerwiec, http://ec.europa.eu/environment/industry/retail/pdf/issue paper_4/ENV-2012-00378-00-00-PL-TRA-00.pdf, 10.09.2015.

ETTG (2014), European Think Tanks Group, Our collective interest: Why Europe's problems need global solutions and global problems need European action, September.

EU FLEGT Facility (2015), http://www.euflegt.efi.int/portal/, 12.09.2015.

EU REDD Facility (2015), http://www.euredd.efi.int/portal/the_facility/t.UNeYQeTWgbQ, 10.09.2015.

EU-Africa Ministerial Statement on Climate Change, Brussels, 2.04.2014, http://europa.eu/rapid/ press-release_STATEMENT-14-97_en.htm, 10.09.2015.

Europe and Former Colonies Urge Action at Rio+20, „Inter Press Service” z 16 czerwca 2012 r.

European Climate Diplomacy (2011), Engaging with Africa on Climate Change. Roundtable Report. Brussels, 14.10.2011, http://ec.europa.eu/clima/events/0043/roundtable_report_en.pdf, 12.09.2015.

European Commission (2009), Communication from the Commission to the Council and the European Parliament, EU Strategy for Supporting Disaster Risk Reduction in Developing Countries, Brussels, 23.02.2009, COM(2009) 84 final.

European Commission (2011), Implementation Plan of the EU Strategy for Supporting Disaster Risk Reduction in Developing Countries 2011-2014, Commission Staff Working Document, Brussels, 16.02.2011, SEC(2011) 215 final.

European Court of Auditors (2013), EU climate finance in the context of external aid, Special Report 17.

Fogler J. (2003/2004), The External Environmental Policy of the European Union, ,Yearbook of International Co-operation on Environment and Development".

Fronia M., Snarska M., Tryjanowski P., Szczyciński J. (2010), Zmiany klimatu w polityce rozwojowej - Kopenhaga i co dalej?, „Global Development Research Group Policy Paper”, nr 3.

General Secretariat of the Council (2014a), Fourth EU-Africa Summit, Declaration, Brussels, 2-3 April 2014, http:/www.consilium.europa.eu/uedocs/cms_Data/docs/pressdata/en/ec/142096.pdf, 10.09.2015.

General Secretariat of the Council (2014b), Fourth EU-Africa Summit, Roadmap 2014-2017. http://www.consilium.europa.eu/uedocs/cms_Data/docs/pressdata/en/ec/142094.pdf, 10.09.2015.

Global Climate Change Alliance+ (2015), http://www.gcca.eu/intra-acp/climate-for-development-in-africa-climdev-programme, 11.09.2015.

Gogo J. (2012), Africa: Rio+20 Shortchanges Continent, „The Herald Online” z 2 lipca.

Healthy Futures (2015), http://www.healthyfutures.eu/, 11.09.2015.

Herrero A., Knaepen H. (2014), Run-up to 2015: A moment of truth for EU external climate action?, „ECDMP Brief Note”, nr 67 - September.

Hudson J., Paul C. (2011), Flegt Action Plan. Progress Report 2003-2010, 26 stycznia 2011, $\mathrm{http} / / /$ ec.europa.eu/development/icenter/repository/flegt_ap_progress_report_2011-03-11_en.pdf, 10.09.2015. 
Ighobor K. (2012), Rio summit keeps African hopes alive, „Africa Renewal” z 7 września 2012 r. IPCC (2001), Third Asssessment Report, Cambridge University Press, Cambridge.

IPCC (2001a), Synthesis Report, Third Assessment Report, Geneva, Intergovernmental Panel on Climate Change.

IPCC (2007), Climate Change 2007: Impacts, Adaptation and Vulnerability (Contribution of Working Group II to the Fourth Assessment Report of the IPCC), Cambridge University Press, Cambridge.

IPCC (2014), Climate Change 2014: Synthesis Report, Cambridge University Press, Cambridge.

IPCC (2014a), Climate change 2014 : Impact, adaptation and vulnerability. Summary for policymakers, AR5 Phase 1 Report Launch, 31 March.

JAES (2007), The Africa-EU strategic partnership, Joint Africa-EU Strategy, http://www.africa-eu-partnership.org/sites/default/files/documents/eas2007_joint_strategy_en.pdf, 12.09.2015.

JAES (2007a), First Action Plan (2008-2010) for the Implementation of the Africa-EU Strategic Partnership, http://www.africa-eupartnership.org/sites/default/files/documents/jaes_action_plan 2008-2010.pdf, 12.09.2015.

JAES (2010), Action Plan (2011-2013), http//www. africa-eupartnership.org/sites/default/files/documents/03-jeas_action_plan_en.pdf, 12.09.2015.

Key Deliverables of the Joint Africa-EU Strategy. Second Action Plan 2011-2013 (Living document, as of July 2012), http://euroafrica-ict.org/files/2012/10/27_07_12_key_deliverables_jaes_second action plan.pdf, 12.09.2015.

Kjellen J. (2004), Pathways to the future, the new diplomacy for sustainable development, „IDS Bulletin", t. 35, nr 3.

Komisja Europejska (2011), Komunikat Komisji do Parlamentu Europejskiego, Rady, Europejskiego Komitetu Ekonomiczno-Spolecznego i Komitetu Regionów, Zwiększanie wplywu unijnej polityki rozwoju. Program działań na rzecz zmian, Bruksela, 13.10.2011, KOM(2011) 637 wersja ostateczna.

Komisja Europejska (2012), Komunikat Komisji do Parlamentu Europejskiego, Rady, Europejskiego Komitetu Ekonomiczno-Społecznego i Komitetu Regionów, Rozwój i koncentracja unijnej wspólpracy międzynarodowej $w$ dziedzinie badań naukowych $i$ innowacji: podejście strategiczne, Bruksela, 14.09.2012, $\operatorname{KOM(2012)~} 497$ wersja ostateczna.

Komisja Europejska (2014), Komunikat Komisji do Parlamentu Europejskiego, Rady, Europejskiego Komitetu Ekonomiczno-Spolecznego i Komitetu Regionów, Godne życie dla wszystkich: od wizji do wspólnego dzialania, Bruksela, 2.06.2014, COM(2014) 335 final.

Kugiel P. (2014), Zmiany we wspólpracy rozwojowej UE: skutki dla Polski, „Biuletyn PISM”, nr 46 (1158), 17 kwietnia.

Łukaszuk L. (2007), Akwakultura - jej znaczenie cywilizacyjne i gospodarcze w polityce morskiej państw i spoleczności międzynarodowej, „Stosunki Międzynarodowe”, nr 3-4.

Ministerstwo Środowiska RP (2009), Komunikat Ministerstwa Środowiska RP, 19.12.2009. http://www.mos.gov.pl/artykul/7_aktualnosci/10668_copenhagen_accord_podczas_cop_15.html, 10.09.2015.

Ministerstwo Środowiska RP (2010), Konferencja klimatyczna COP 16-podsumowanie, Komunikat Ministerstwa Środowiska RP, 12.12.2010, http://www.mos.gov.pl/artykul/7_aktualnosci/13881_konferencja_klimatyczna_cop_16_podsumowanie.html, 10.09.2015.

Ministerstwo Środowiska RP (2011), Przetom na szczycie klimatycznym ONZ - kontynuacja Protokolu z Kioto, w przyszlości zobowiqzania dla wszystkich, Komunikat Ministerstwa Środowiska RP, 9.12.2011, http://www.mos.gov.pl/artykul/7_aktualnosci/17526_przelom_na 
szczycie_klimatycznym_onz_kontynuacja_protokolu_z_kioto_w_przyszlosci_zobowiazania_ dla_wszystkich.htm, 10.09.2015.

Nyamu-Musembi C., Cornwall A. (2004), What is the rights-based approach all about? Perspectives from international development agencies, „IDS Working Paper”, nr 234, Institute of Development Studies, Brighton.

Nyong A. (2011), Skutki zmian klimatycznych w tropikach - przypadek Afryki, w: Zmiany klimatyczne - impas i perspektywy. Punkt widzenia krajów globalnego Poludnia, red. M. Brennek, Polska Akcja Humanitarna, Warszawa.

Pierwszy krok Zielonego Funduszu Klimatycznego, 26.05.2011, http://globalnepoludnie.pl/Pierwszy-krok-Zielonego-Funduszu, 10.09.2015.

Reid H., Alam M. (2011), Zmiany klimatyczne i Milenijne Cele Rozwoju, w: Zmiany klimatyczne - impas i perspektywy. Punkt widzenia krajów globalnego Poludnia, red. M. Brennek, Polska Akcja Humanitarna, Warszawa.

Rio+20 - wiele hatasu po nic, 27.06.2012 r., http:/www.chronmyklimat.pl/negocjacje-klimatyczne/14511-rio20-wiele-halasu-po-nic, 12.09.2015.

Rio+20: Agreement reached, say diplomats, „BBC News” z 19 czerwca 2012 r.

Shukla P. R. (2011), Klimat i rozwój - pożqdane polqczenie, w: Zmiany klimatyczne - impas i perspektywy. Punkt widzenia krajów globalnego Poludnia, red. M. Brennek, Polska Akcja Humanitarna, Warszawa.

Stern N. (2007), The Economics of Climate Change, Cambridge University Press, Cambridge.

Supporting a climate for change - 2011. The EU and developing countries working together, European Commission, Brussels 2011.

TerrAfrica (2015), http://www.terrafrica.org/, 10.09.2015.

The European Forest Institute (2009), What is a Voluntary Partnership Agreement? The European Union Approach, „EFI Policy Brief”, nr 3, http://ec.europa.eu/development/icenter/repository/Flegt_efi_policy_brief_3_eng.pdf, 12.09.2015.

The Multiannual Financial Framework: The external action financing instruments, Memo, Brussels.

Tondel F., Knaepen H., van Wyk L.-A. (2015), Africa and Europe Combatting Climate Change. Towards a Common Agenda in 2015, „ECDPM Discussion Paper”, European Centre for Development Policy Management nr 177, maj.

Torney D. (2012), Europe can do better, in „China dialogue”, https://www.chinadialogue.net/article/4931-Europe-can-do-better.

Torney D. (2013), European climate diplomacy: Building capacity for external action, Briefing Paper 141, Finnish Institute of International Affairs, October.

TWN (2012), TWN Info Service on Climate Change (Oct12/06), 27.10.2012, http://www.twn.my/ title2/climate/info.service/2012/climate20121006.htm, 12.09.2015.

Umowa o partnerstwie między czlonkami grupy państw Afryki, Karaibów i Pacyfiku, z jednej strony, a Wspólnota Europejska i jej Państwami Czlonkowskimi, z drugiej strony, podpisana w Kotonu dnia 23 czerwca 2000 r., Dz.U. L 317, 15.12.2000.

UN (2012), The future we want, Resolution adopted by the General Assembly on 27 July 2012. A/RES/66/288.

UNEP (2013), Africa Adaptation Gap Technical Report: Climate-change Impacts, Adaptation Challenges and Costs for Africa, Nairobi.

UNFCCC (1992), United Nations Framework Convention on Climate Change (FCCC/INFORMAL/84), http://unfecc.int/resource/docs/convkp/conveng.pdf, 10.09.2015. 
UNIC Warsaw (2013), http://www.unic.un.org.pl/unic-activities/nowe-strony:-agenda-rozwoju-po-roku-2015/2465, 10.09.2015.

University of Liverpool (2015), QweCI project, http:/www.liv.ac.uk/qweci/, 11.09.2015.

W kierunku światowej gospodarki ekologicznej i lepszego zarzadzania - Komisja przedstawia zatożenia polityczne na konferencję Rio +20, Bruksela, „Press Release” z 20 czerwca 2011 r.

Yamin F., Rahman A., Huq S. (2011), Podatność na zmiany klimatyczne, przystosowanie do nich i klesski żywiotowe, w: Zmiany klimatyczne - impas i perspektywy. Punkt widzenia krajów globalnego Poludnia, red. M. Brennek, Polska Akcja Humanitarna, Warszawa.

Yunus M., Camdessus M. (2012), Africa after Rio+20, „The Huffington Post” z 22 czerwca.

\section{Streszczenie}

Celem artykułu jest przedstawienie i scharakteryzowanie polityki UE w zakresie przeciwdziałania zmianom klimatu oraz ochrony środowiska na kontynencie afrykańskim w kontekście szerszego celu jakim jest ograniczenie (eliminacja) ubóstwa. Istnieje coraz większa zgoda co do tego, że potrzebne jest zintegrowane podejście do zmian klimatu oraz rozwoju. Tylko powiązanie tych kwestii daje możliwość uchwycenia całej złożoności problematyki ubóstwa, która ma charakter wielowymiarowy. Globalny rozwój wymaga uwzględnienia zagadnień związanych z podatnością na zmiany klimatu i przystosowaniem się do nich. W artykule podjęto się próby odpowiedzi na pytanie w jakim stopniu zmiany klimatu są poważnym i stałym zagrożeniem dla rozwoju, jakie zależności zachodzą między nimi. Przedstawiano rolę i znaczenie zmian klimatu i ochrony środowiska w polityce rozwojowej UE. Scharakteryzowano najważniejsze dokumenty i postanowienia w tym zakresie. W szczególności skoncentrowano się na omówieniu problematyki zmian klimatu i rozwoju w relacjach UE-Afryka. Wskazano na najważniejsze wyzwania związane z implementacją polityk łączących klimat i rozwój. Choć bowiem istnieje przekonanie i świadomość współzależności obu tych zjawisk (procesów) to koniecznych działań jest wciąż zbyt mało. Często bowiem działania rozwojowe i klimatyczne traktowane i realizowane są osobno.

Słowa kluczowe: zmiany klimatu, ochrona środowiska, zrównoważony rozwój, polityka rozwojowa, polityka zagraniczna i zewnętrzna UE, Afryka

\section{Development and climate change in the external policy of the European Union - the example of Africa}

\section{Summary}

The aim of this paper is to present and describe the EU's policy with regard to environmental protection and countering climate change in Africa, in the context of the broader objective of reducing, or eliminating poverty. It is increasingly accepted that we need an integrated approach to climate change and development; only by linking these issues together can we show the entire complexity of the multidimensional issue of poverty. Global development requires taking into account issues related to susceptibility and adjustment to climate change. The paper seeks to answer the questions of the extent to which climate change is a serious and lasting threat to development, and about the relations between climate change and development. It presents the role and significance of climate change and environmental protection in EU development policy; it 
describes the major relevant documents and decisions. The author focuses particularly on discussing the issues of climate change and development in the relations between the EU and Africa, and points out the key challenge related to the implementation of policies combining climate and development. Although there is a general conviction about, and awareness of the interrelation of these two phenomena (processes), still too few of the necessary actions are being taken, and the activities related to development and climate are often approached and executed separately.

Key words: climate change, environmental protection, sustainable development, development policy, EU foreign and external policy, Africa 
